\title{
Mânilerden Kalyonları Öğrenmek: \\ Ramazan-nâme Metnindeki Osmanlı Kalyonları ile İlgili Bilgilerin Değerlendirilmesi
}

Yusuf Alperen Aydin*

Learning Galleons from Mânis: The Evalutation of Information About Ottoman Galleons in Ramazan-nâme

Abstract $\square$ Ottoman naval history has emerged and attracted attention as a field of history that is comprehensively studied. One of its primary subjects is unsurprisingly the Ottoman Navy. The academic research in this field is generally based on the archival documents. Besides these, however, Ottoman literary works also contain valuable and rich information regarding the Ottoman Naval History, which also include mânis of folk literature. Published by Âmil Çelebioğlu, Ramazan-nâme is a manuscript that contains mânis, and one of them mentions the galleons of the Ottoman navy in the $18^{\text {th }}$ century. It offers us a different kind of source through which the naval history might be reevaluated. This paper studies the descriptions of the galleons mentioned in the mâni based on the archival documents and modern works. The dating of this text is also established with the aid of historical research on the galleons in question. Available archival documents reveal that these galleons were available in the Ottoman naval inventory until the 1750 s at the latest. Furthermore, it is also revealed that the fact that the names of the galleons were subjects of such a literary mani stemmed partly from the successful Ottoman Mora campaign (1716-1718).

Keywords: Ramazan-nâme, Mâni, Ottoman Navy, Galleon Names, Mora Campaign

\section{Giriş}

Bu çalışmada Ramazan-nâme başlıklı bir yazmanın daha önce Âmil Çelebioğlu tarafından yapılan neşrinde yer verilen bir mânideki kalyon isimleri ${ }^{1}$ üzerinde

* İstanbul Üniversitesi.

1 Âmil Çelebioğlu, Ramazan-nâme, 1826 Yilından Ramazan Mânileri, İstanbul 1974, s. 161-163. 
durulacaktır. Söz konusu kalyonların çoğunun 18. yüzyılda Osmanlı donanması envanterinde yer aldığını daha önceki bir çalışmamıza istinaden söyleyebiliriz. ${ }^{2}$ Burada hem bu kalyonlar hem de isimlerinin okunması hususunda getirdiğimiz okuma teklifleri dolayısıyla diğer kalyonlardan yola çıkılarak mânide zikredilen bütün kalyonların tespiti ile bunlarla ilgili bilgilere yer verilecektir. Böylece hem mâninin meydana getirildiği muhtemel tarihe işaret edilecek hem de bu mânide niçin aşağıda isimleri belirtilen kalyonların zikredildiği anlaşılmaya çalışılacaktır. Osmanlı dönemindeki edebiyat eserlerinde geçen bilgilerin nasıl kullanılabileceğine dair bir deneme niteliği taşıyan sınırları gayet belirli ve aynı zamanda dar tutulan bu makale, Osmanlı Denizcilik Tarihi'nin arşiv dışındaki kaynaklarının nasıl değerlendirileceğine dair bir çaba olarak görülmelidir.

Mâni, Türk Halk Edebiyatı'nda edebi bir tür olarak yer bulmaktadır. Kelimenin anlamı ve etimolojisi üzerine farklı yorumlar vardır. Konumuzun esasıyla doğrudan ilgili olmadığı için burada detaylıca zikredilmesine gerek duyulmadığından Farsça, Arapça veya Türkçe’den türetilen bir kelime olduğuna dair yorumlar bir yana bırakılırsa, Mâni’nin, kısaca ezgi ile söylenen, hece vezni biçiminde dile getirilmiş sözlü olarak ortaya çıkan ve genellikle anonim eserler olduğu ifade edilmektedir. ${ }^{3}$

Bu türden eserlerle ile ilgili yapılan en ayrıntılı bir sınıflandırmada mâniler yapı, hazırlanış ve uygulanış ile konularına göre üç başlık altında toplanmaktadır. Buna göre Ramazan mânileri, son başlık altında değerlendirilmektedir. ${ }^{4}$ Osmanlı döneminde özellikle İstanbul'da Ramazan ayı boyunca hergün iftar ve sahurda okunan mânilerde birbirinden farklı temalar işlenmekteydi. Bu makalede konu edilen Ramazan-nâme isimli eserde Ramazan ayında okunan mâniler kaydedilmiştir. Dolayısıyla eser, Ramazan ayının girdiğini haber veren ilk mâni ile başlamakta sonrasında birbirinden farklı konuları işleyen mâniler yer almaktadır.

Ramazan-nâme üzerine çalışan Â. Çelebioğlu, mânilerdeki yer isimlerinden hareketle eserin teşekkül bölgesinin İstanbul olduğuna kanaat getirmektedir. Yine bazı mânilerdeki ifadelerden yola çıkıp eserin muhtemel müellifi veya hiç olmazsa derleyicisi olarak Emir Mustafa isimli bir yeniçeriyi işaret etmektedir. Eserin tek bir müellifi olması gerektiğine dair görüşüne delil olarak da mânilerin büyük

2 Yusuf Alperen Aydın, Sultanın Kalyonları, Osmanlı Donanmasının Yelkenli Savaş Gemileri (17011770), İstanbul 2011.

3 Abdülkadir Emeksiz, İstanbul Mânileri, İstanbul 2007, s. 10, 11, 18; Nurettin Albayrak, "Mâni”, Türkiye Diyanet Vakfı İslâm Ansiklopedisi (DİA), XXVII (2003), s. 572.

4 Emeksiz, İstanbul Mânileri, s. 19-20. 
ölçüde bir uslup birliği içerisinde bulunmasını göstermektedir. Dolayısıyla eserin meydana getiriliş zamanı ile ilgili son tarihi, Yeniçeri Ocağı’nın kaldırıldığı 1826 yll ş̧eklinde vermektedir. ${ }^{5}$

Yine Â. Çelebioğlu, eserin muhtemel müellifinin en erken hangi tarihte söylenmiş mânileri kaydettiğine dair bazı bilgilere de temas etmiştir. Bir mânide Ahırkapı ile Çatladıkapı arasında inşa edilen fenerden bahsedilmesinden ve mâniyi söyleyen kişinin bu feneri inşasından biraz sonra gördüğünü ifade etmesinden dolayı, bu inşa tarihinin tespiti ile Ramazan-nâme isimli eserin teşekkül veya tertibine en yakın ve en doğru tarihin ortaya çıkarılacağını belirtmiştir. ${ }^{6}$ Çelebioğlu, bu tarihle ilgili başka bir açıklamada bulunmamıştır. Söz konusu fener III. Osman'ın saltanatı yıllarında (1754-57), Kumkapı açılarında 1756'da meydana gelen bir deniz kazasından sonra inşa edilmiştir. ${ }^{7}$ Çelebioğlu açıkça bu olayın tarihini zikretmemekle birlikte buradan hareketle eserin zaman bakımından 18 . yüzyılın ikinci yarısında teşekkül ettiği tahmininde bulunmuştur. ${ }^{8}$

Ramazan-nâme isimli bu eser diğer hususiyetleri yanında denizcilik tarihi bakımından da bazı önemli bilgilere ulaşmayı sağlayacak vasıftadır. Bu cümleden olarak eserdeki "Kalyonlar Faslı" kısmı hayli ilginç veriler sağlamaktadır. Burada adı zikredilen kalyonlarla ilgili arşiv belgelerinin tespit edilmesi, sadece söz konusu gemilerin mevcudiyeti ve halk arasında nasıl tanındığı değil, eserin kesin tarihlendirme meselesine de ışık tutacaktır. Aslında Osmanlı dönemine ait bazı edebi eserlerde gemilerle ilgili konulara sık rastlanmaktadır. Â. Çelebioğlu da, bir makalesinde Halk ve Divan şiirinde gemiyle ilgili özellikleri üç grup altında incelemenin mümkün olduğunu ifade etmektedir. Ona göre birinci grupta gemi türleri ve bunların donanımlarının doğrudan veya benzetmelerle zikredildiği şiirler; ikinci grupta gemi, gemicilik, deniz ve deniz savaşlarını konu alarak bunları anlatan, açıklayan, öven veya hikaye türünden müstakil eserler ya da bir eserin içinde parçalar halindeki şiirler; üçüncü grupta ise gemicilerin kullandığı terimlerle yazılımış şiirler bulunmaktadır. ${ }^{9}$

5 Çelebioğlu, Ramazan-nâme, s. 16-17.

6 Çelebioğlu, Ramazan-nâme, s. 18.

7 Fikret Sarıcaoğlu, “Osman III”, DİA, XXXIII (2007), s. 459. 1758 yılı sonlarında Çatladıkapı Feneri’ne kurşun gönderilmesi hakkında bkz. Miraç Tosun, "Şan-1 Devlet-i Aliyye’yi Korumak ya da Edirne Sarayı'nı Tamir Etmek” Journal of History Studies, 184 (2014), s. 187 (dip not 27).

8 Çelebioğlu, Ramazan-nâme, s. 18.

9 Âmil Çelebioğlu, "Eski Türk Edebiyatında Gemiyle İlgili Şiirler ve Bazı Hususiyetler”, Eski Türk Edebiyatı Arasstırmaları, İstanbul 1998, s. 626. 
Bu çalışmada üzerinde durulacak olan mâniyi Çelebioğlu, söz konusu makalesinde ikinci gruptakilere bir örnek olarak daha önce yaptığı yayına atfen vermiştir ${ }^{10}$ :

\section{KALYONLAR FASLI}

1

Gûş edin neler söyleyem

Tersâne vasfin söyleyem

Ağalarıma bu gece

Kalyonları vasf eyleyem

3

Vardokasta Üçanbarlı

Dağ gibidir Üçkantarlı

Her biri bir kal'a değer

Yiğitleri olur arlı

5

Âdemin erişmez aklı

Dille mümkün değil nakli

Mâvi kıçlı bî-bedeldir

Biri de sarı Kuşaklı

7

Çıktıkta bahre İryâle

Küffâr alayına sala

Umarız Malta kâfirin

Vardakostasını ala

9

Barkıçlının vasfın sorma

Kıratbaşı deyip durma

Deryâ-yı aşkta gösterir

Reftârı Yaldızlı Hurma

11

Kilîd-i bahrîdir biri

Çifte belâ yanda biri

Karavele kuş misâli

Deryâda uçmakta biri
2

Şevket-i âli Osmân'a

Revnak verendir tersâne

Dağ gibi kalyonlarımız

Dâğ-1 derundur düşmana

4

Deryâda ünvan gösterir

Ziyneti elvan gösterir

Seyr eyle Yaldız Kıçlıyı

Mânend-i hûban gösterir

6

Kapudane dehr(e) yürür

Gûyâ ki bir servet yürür

Baturna bir kal'a değer

Deryâda serbeser yürür

8

Şâhin gibi İsperkıçlı

Mâhitabdır Yaldızkıçlı

Mevlâ hatâdan saklasın

Hakka güzeldir Aykıçlı

10

Sinab'dan ikisi geldi

Malta'nın bağrını deldi

Çifte Bahçeli birisi

Ejderbaşlı da güzeldi

12

Yoktur nazîri bunların

Bağrını yakar küffârın

Sizlere eyledik tamam

Evsâfını kalyonların

10 Makalede yer verilen mâni (a.g.m., s. 650) ile bunun daha önceki yayını (Ramazan-nâme, s. 161-163) arasında bazı küçük farklar bulunmaktadır. Burada Ramazan-nâme’deki mâni esas alınmıştır. 
Osmanlı donanması kalyonları dönemindeki diğer devletlerin kalyonları ile boy ölçüşen evsaftaydılar. Mânide de belirtildiği gibi döneminde bunları bizzat görenler üzerinde etkileyici bir görünüşe sahiptiler. Bununla ilgili bir örnek III. Ahmed devrine (1703-30) aittir. 1721'de İstanbul'da bulunan İran elçisi ve beraberindeki heyete Tersane-i Âmire gezdirilmişti. Dönemin kroniğinde bu gezintinin amaçlarından birinin, Kur'an'daki "Denizde yüce dağlar gibi yükselen gemiler de O'nundur ${ }^{11 "}$ ", meâlindeki ayetin ne anlam ifade ettiğinin elçiye gösterilmesi olduğu kaydedilmektedir. Elçilik heyetindekiler de şaşkınlık ve hayretle bu gösterişli kalyonları seyretmişlerdir. ${ }^{12}$ Hatta elçilik heyetinden birisi bir kalyondaki üç kantarlık topun büyüklügü karşısında hayretini bir adım daha öteye taşıyarak topun içine girmeye çalışmıştır. ${ }^{13} \mathrm{Bu}$ durum böyle abartılı olmamak kaydıyla batılılar için de geçerli gözükmektedir. 1740 yazı başlarında Tersane'yi gezen P. Pococke adlı bir İngiliz, burada gördüğü en büyük kalyonun 110 toplu, 1600 personeli bulunan bir üç ambarlı kalyon olduğunu ve bunun İngiliz donanmasının en modern gemilerine benzediğini zikretmekle yetinmiştir. ${ }^{14}$

Tekrar mâniye dönersek, hemen akla şu sualler gelir: Mânide yer verilen kalyonlar acaba sadece etkileyici olmaları dolayısıyla mı mâniyi dile getiren tarafından kayda değer bulunmuşlardı? Yoksa bir deniz savaşı kazanan donanmada yer alan gemiler oldukları için mi övülmüşlerdi? Ya da bir Ramazan gününde İstanbul halkının aşina oldukları Osmanlı donanması kalyonları üzerine de bir mâni söylemek lüzumu mu hissedilmişti? Bu ve benzeri sorulara doğru bir zeminde cevap verebilmek için öncelikle "tarihi temele" inmek gerekir. Bunun için de evvela mânide zikredilen kalyonların isimlerinden başlamak açılayıcı olur. Müellif tarafından vasıflarıyla belirtildikleri ifade olunan kalyonlar şunlardır: Kapudane, Baturna [Patrona], Iryâle [Riyale], Üç anbarl, Ü̧̧ kantarl, Mavi kıçl, İsper [Esper] kıçl, Yaldız kıçli, Ay kıçli, Bar [Nar] kıçl, Yaldızlı hurma (kıçli), Çifte bahçeli, Ejder başli, Kır At başli, Kilîd-i bahrî, Çifte belâ [Balaban], Karavele ve Sarı kuşaklı.

$\mathrm{Bu}$ adların hangi düşünüşün eseri olarak kalyonlara verildiği noktasında şunları söylemek mümkündür. Osmanlı donanmasında görev aldıkları ilk yıllarda

11 Rahman sûresi, 24. ayet, Kur'ân-ı Kerîm ve Açıklamalı Meâli, haz. H. Karaman vd., Ankara 2006, s. 531.

12 Râşid Mehmed Efendi ve Çelebizâde İsmail Âsım Efendi, Târîhb-i Raşsid ve Zeyli, II, haz. A. Özcan v.d., İstanbul 2013, s. 1282.

13 Râşid Mehmed Efendi, Târîh-i Râşid ve Zeyli, II, s. 1283.

14 Wolfgang Müller-Wiener, Bizans'tan Osmanliya İstanbul Limanı, İstanbul 1998, s. 51, 199-dip not 80 . 
kalyonların kayıtları genel olarak Sakızlı Ahmed Kaptan'ın kalyonu, Cezayirli Mustafa Kaptan'ın kalyonu vs. gibi kalyonlara kumanda eden kaptanlarının adı ile olmaktaydı. Sonraki yıllarda kalyonlar baş figürleri (Ejder başlı) veya aynalık da denilen pupa/kıçlarına çizilmiş tasvirlerle $(A y k \imath c ̧ l)$ yahut kıç kasaralarındaki balkon tarzı süslü yapıları dolayısıyla (Çifte bağģeli), bordalarındaki boyanın ren-

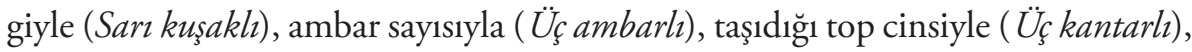
gemi türüyle (Karavele), bir çarpışmada ele geçirilmiş ise bu belirtilerek (Maltız akdarması) vs. isimlendirilmişlerdir. ${ }^{15}$

18. yüzyıl arşiv belgelerinde kaptan adı belirtilmeden kaydedilen ilk kalyon Kırmızı kıçlı adını taşır. 1705 'te Tersane'de demirli olan bu kalyon 1710 'da fesh edilmek suretiyle yani parçalarına ayrılarak hizmetten çıkarılmıştır. ${ }^{16}$ Donanma kalyonlarının ilk kez baş veya kıç figürleriyle yahut kıç kasaralarındaki balkon tarzı yapıyla isimlendirilmeleri 1714 yılında olmuştur. ${ }^{17}$ Daha sonraki yıllarda ise kalyonların isimlendirilmelerinde baş figürleri ve kıçlarındaki tasvirlerden ziyade Esed-i Bahrî, Fâtih-i Bahrî gibi isim tamlamaları kullanılmıştır. ${ }^{18}$

\section{1-2-3- Kapudane, Baturna [Patrona], İryâle [Riyale] kalyonları:}

Osmanlı donanmasının en yüksek mevkideki üç komutanına (Kapudane-i hümayun, Patrona-i hümayun, Riyale-i hümayun) görevleri dolayısıyla tahsis edilen kalyonlar, onların rütbeleriyle yani Kapudâne, Patrona veya Riyâle kalyonu şeklinde isimlendirilmişlerdir. Fakat burada dikkat edilmesi gereken husus 18. yüzyılda da örneklerine rastlanıldığı üzere bir kalyonun sürekli olarak Kapudane-i hümayun kalyonu olarak hizmet görmediğidir. Dolayısıyla donanmada zaman içerisinde bu rütbe isimleriyle kaydedilen muhtelif kalyonlar olmuştur. Mânide geçen Kapudane, Baturna [Patrona], İryâle [Riyale] kalyon isimleri spesifik bir tarihlendirme yapma konusunda yardımcı olmamaktadır.

\section{4- $\ddot{U}_{\zeta}$ anbarl kalyon:}

Ana güvertelerinin altındaki ambar sayısı üç olan kalyonlar için genel olarak "Üç ambarlı kalyon” tabiri kullanılmaktaydı. Bu tür kalyonlar ambarları dolayısıyla

15 Donanma kalyonlarının isimlendirilmesi hakkında bkz. Aydın, Sultanın Kalyonları, s. 117-118.

16 Aydın, Sultanin Kalyonları, s. 117.

17 Aydın, Sultanın Kalyonları, s. 118.

18 Aydın, Sultanın Kalyonları, s. 121-122. Bu konuda ayrica bkz. Tuncay Zorlu, Osmanl ve Modernleşme, III. Selim Dönemi Osmanl Denizciliği, İstanbul 2014, s. 199-207. 
çok sayıda top taşıyabilmekteydiler. 1701'de 60 zirâ $(45,48 \mathrm{~m}$.) uzunluğundaki bir üç ambarlı kalyonun 130 topu yine 1715'te Akdeniz'e açlan donanmada 62 zirâ $(46,99$ m.) uzunluğunda başka bir üç ambarlı kalyonun da 130 topu bulunmaktaydı ve bu kalyon Kapudâne-i hümayuna tahsis olunmuştu. ${ }^{19} 1736$ 'da Çifte Aslan kıçlı ve Çifte Kaplan kıçlı isimlerindeki üç ambarlı kalyonlar Tersane'de tamir görmekteydiler. ${ }^{20} 1754$ 'te Tersane'de 61,5 zirâ (46,61 m.) uzunluğunda Nüvîd-i Fütûh isimli üç ambarlı kalyon denize indirilmişti. ${ }^{21} 1766$ 'da denize indirilen başka bir üç ambarlı kalyona ise Mesken-i Gāzî adı verilmişti. ${ }^{22}$

Bu bilgiler dolayısıyla mânide geçen $\ddot{U} c ̧$ anbarlı ifadesinin de tarih konusunda kesin bir şey ifade etmeye imkan vermediği anlaşılacaktır. Mânide bundan önce "Vardakosta" kelimesi de geçmektedir. Bu kelime, kıyı savunmasında kullanılan gemi anlamındaki İtalyanca "guardacosta"dan gelmektedir. ${ }^{23} 1724$ 'te Esper kıçl ve Şahin kıçlı kalyonlara benzer şekilde 53,5 (40,55 m.) ve 51,5 (39,03 m.) zirâ uzunluklarında vardakosta türünde iki kalyonun Tersane'de inşâ edilmesi emredilmişti. ${ }^{24}$ Dolayısıyla "Vardakosta" kelimesi de özel bir isimlendirme olmadığından tarihlendirme için bir veri sağlamamaktadır.

\section{5- Ü̧̧ kantarlı kalyon:}

Üç kantar (169,34 kg.) ağıllığında gülleler atan topları bulunan kalyonlar "Ü̧̧ kantarli" olarak da nitelendirilmekteydi. Donanmada 1717 'de Yılan başlı isminde üç kantarlı topu olan bir kalyon bulunmaktaydı ve listelerde kendi isminin yanında $\ddot{U}_{\zeta}$ kantarlı ifadesi de vardı. Daha sonraki yıllarda da bu türden kalyonlar donanmada görev almıştı. Örneğin 1737 'de hizmete giren ve su aldığı için üç sene sonra hizmetten çıkarılan 55,5 zirâ (41,69 m.) uzunluğundaki Şeşpâ-yı Bahrî isimli kalyon, 1753 'te Tersane'de denize indirilen 55,5 zirâ (41,69 m.) uzunluğundaki başka bir kalyon ${ }^{25}$ ve 1758 'de donanmaya katılan Hısn-ı Bahrî isimli kalyonlarda da üç kantarlı top bulunmaktaydı. ${ }^{26}$

19 İdris Bostan, Kürekli ve Yelkenli Osmanlı Gemileri, İstanbul 2005, s. 331.

20 Bostan, a.g.e, s. 331.

21 Şem'dânî-zâde Findıklılı Süleyman Efendi, Mür'’’t-Tevârih, haz. M. Aktepe, İstanbul 1976, I, 175.

22 Çeşmî-zâde Mustafa Reşîd, Çeşmî-zâde Tarihi, haz. B. Kütükoğlu, İstanbul 1993, s. 23.

23 Henry \& Renée Kahane, Tietze, The Lingua Franca in the Levant, Turkish Nautical Terms of Italian and Greek Origin, İstanbul 1988, s. 454.

24 Aydın, Sultanin Kalyonları, s. 65.

25 Bostan, Osmanl Gemileri, s. 352-53.

26 Şem'dânî-zâde, Mür'itt-Tevârih, haz. M. Aktepe, İstanbul 1978, II. A, s. 16. 


\section{6- Karavele kalyon:}

Karavele, denizcilik literatüründe kalyondan farklı bir gemi türüdür. Portekiz ve İspanyollar tarafından özellikle 16. yüzyılda keşif ve araştırma gemisi olarak kullanılmıştır. İlk örnekleri Latin yelkenlidir. Bununla birlikte kare yelken taşıyan, iki veya üç direği bulunanları da vardır. Kalyonlarınkine kıyasla pek yüksek olmayan bordasıyla ve uzunluğuyla kalyonlardan küçük boyutlara sahiptir. Osmanlı donanmasındaki karavele tipi yelkenli gemiler bilhassa Ege denizindeki küçük adaların limanlarında ve sığ sularda saklanan korsan gemilerinin takipinde etkili olmaktaydılar. Genelde 38,5 zirâ (29,18 m.) ile 43,5 zirâ (32,97 m.) arasında değişen uzunluklarıyla çok sayıda karavele donanmada hizmet görmüştür. ${ }^{27} \mathrm{Bu}$ tip gemilerin isimlendirilmelerinde karavele oldukları da kaydedilmekteydi. Dolayısıyla mânide kalyonun adının sadece karavele olarak zikredilmesi belirleyici bir özellik değildir.

\section{7- Bar [Nar] kıçlı kalyon:}

Osmanlı donanmasında 18. yüzyılda mânide zikredilen şekilde bir kalyon ismine rastlanmamıştır. Fakat "be" olarak okunan harf "nun" olarak dikkate alınırsa bu kez "Nar" kelimesi ortaya çıkar. ${ }^{28}$ Donanmada Yaldızlı Nar kıçl isimli bir kalyonun kaydına ilk kez 1714 yılında rastlanmaktadır. ${ }^{29}$ Bu kalyon 1740 'da hizmetten çıkarılarak kiremitçi esnafına 2150 kuruşa satılmıştır. ${ }^{30}$

\section{8- Çifte belâ [Çifte Balaban]}

18. yüzyılda Osmanlı donanmasında "Çifte bela" isminde bir kalyona tesadüf edilmemiştir. Bu durum kelimenin başka türlü okunduğu ihtimalini akla getirmektedir. Özellikle mânide zikredilen kalyonların bir kısmının dahil olduğu 1730 yılına ait bir listede ise Çifte Balaban kıçl adında karavele tipi bir kalyon bulunmaktadır. ${ }^{31}$ Muhtemelen mânide "Çifte belâ yanda biri" şeklinde verilen ifadedeki Arapça "ye" harfinin "be" olarak dikkate alınmasıyla bu dizenin "Çifte Balaban da biri” olarak okunması daha makul gözükmektedir.

27 Aydın, Sultanın Kalyonları, s. 60.

28 Çelebioğlu'nun da eserde harflerin noktaları ile ilgili bu şekilde tespit ettiği bazı örnekler için bkz. Ramazan-nâme, s. 30.

29 Başbakanlık Osmanlı Arşivi (BOA), MAD 3171, vr. 36a; Aydın, Sultanın Kalyonları, s. 357.

30 BOA, MAD 3389, s. 114; Aydın, Sultanın Kalyonlart, s. 136.

31 Aydın, Sultanın Kalyonları, s. 55. 
1723 'te denize indirilen 38,5 zirâ (29,18 m.) uzunluğundaki Çifte Balaban kıçlı isimli bu kalyon Osmanlı donanmasında hizmet görürken savunmalarını güçlendirmeleri için 1732 'de Trablusgarb Ocağı' na hibe olunmuştu. ${ }^{32}$

\section{9- Kilîd-i bahrî kalyonu}

Ramazan-nâme isimli eserin muhtemel teşekkül tarihini Çatladıkapı ile Ahırkapı arasındaki fenerin inşa edildiği 1756 yılı olarak değerlendiren Çelebioğlu'nun görüşü dikkate alındığında bu yılın öncesi ve sonrasında "Bahrî" kelimesi ile yapılan tamlamaların bazı donanma kalyonlarına isim olarak verildiği belgelerden anlaşılmaktadır. 1730 ile 19. yüzyılın hemen başları arasında tespit edilebildiği kadarıyla bu kalyonlar şunlardır: Melek-i Bahrî, Şeşpâ-yı Bahrî, Esed-i Bahrî, Fâtih-i Bahrî, Hümâ-yı Bahrî, Tayyâr-ı Bahrî, Tombaz-ı Bahrî, Gazâl-ı Bahrî, Seyyâr-ı Bahrî, Şehbâz-ı Bahrî, Ejder-i Bahrî, Sayyâd-ı Bahrî, Zîver-i Bahrî, Nâsır-ı Bahrî, Neheng-i Bahrî, Tâvus-ı Bahrî, Ankā-yı Bahrî, Hısnül-bahr (Hısn-ı Bahrî), Semend-i Bahrî, Peleng-i Bahrî, Tılsım-ı Bahrî, Sebk-i Bahrî, Hırz-ı Bahrî, Ukāb-ı Bahrî̉ ${ }^{33}$, Arslan-ı Bahrî, Kaplan-ı Bahrî. ${ }^{34}$

Arşiv belgelerinde 18. yüzyıl kalyonları arasında mânide zikredilen şekliyle Kilîd-i Bahrî olarak geçen bir kalyona tesadüf edilmemiştir. Ancak, Ahmed Cevdet Paşa, 1801'de donanma kalyonları arasında Kilidül-bahir isimli kalyonun yanı sıra Seddül-bahir isimli bir kalyonu da kaydetmektedir. ${ }^{35} 7$ Ağustos 1800 tarihli bir belgede ise yeni inşa edildiği belirtilen Seddül-bahir kalyonu için tunç top dökülmesi emredilmektedir. ${ }^{36}$ Muhtemelen aynı tarihlerde donanma hizmetine giren bu kalyonlara Çanakkale boğazının tahkimi için yaptırılan kalelerin isimleri verilmiş olmalıdır. Kilîdül-bahir kalyonu ile ilgili daha sonraki bir bilgi 1807 yılının Haziran ayındaki Osmanlı-Rus donanmalarının çarpışmasına dairdir. Kalyonun adı bu listede Kilìd-i bahrî olarak zikredilmektedir. ${ }^{37}$ Bu çarpışmada ağır hasar alan Seddül-bahir kalyonu ise Osmanlı donanmasının diğer kalyonları çekilince Rus donanmasına teslim olmak zorunda kalmıştı. ${ }^{38}$

32 BOA, MAD 10325, s. 32-33.

33 Aydın, Sultanin Kalyonları, s. 121-126.

34 BOA, C. BH 893; 1154; 2196.

35 Bostan, Osmanli Gemileri, s. 442.

36 BOA, C. BH 5534.

37 John Tredrea-E. Sozaev, Russian Warships in the Age of Sail, 1696-1860. Design, Construction, Careers and Fates, Great Britain 2010, s. 16.

38 Tredrea-Sozaev, Russian Warships, s. 102. 
Mâninin tarihlendirilmesi yolunda en sorunlu gözüken husus Kilîd-i bahrî kalyonu dolayısıyla olmaktadır. Bu durumda iki türlü düşünmek gerekmektedir. Birincisi mânide zikredilen ismin doğru kabul edilmesi halinde mâninin söylendiği tarihin 1807 ve belki biraz sonrası olarak kabul edilmesi gerekliliğidir. Fakat bu kez Çatladıkapı ile Ahırkapı arasında inşa edilen fenerin tarihinden elli, elli beş sene sonrasına ait bir kalyonun adının zikredilmesi Ramazan-nâménin muhtemel müellifinin bu mâniyi söyleyen kişi olamayacağı ihtimalini akla getirmektedir.

İkinci yaklaşım kalyonunun isminin aslında başka bir isim olduğu fakat mânide Kilìd-i Bahrî olarak yazıldığıdır. Daha doğrusu donanmanın resmi kayıtlarında başka bir isimken mâniyi söyleyen tarafından bu ismin kullanılmadığıdır. Buna benzer bir örnek Bababurun'da 1727 Mayısında inşâsına başlanan kaleyle ilgilidir. Kale, inşası bittiğinde Hırzül-bahrî ismiyle arşiv belgelerinde kaydedilirken daha sonra Babakale olarak tesmiye olunmuștur. ${ }^{39}$ Ramazan-nâme'nin muhtemel müellifinin gördüğü Çatladıkapı ile Ahırkapı arasında inşa edilen fenerin yapım tarihinin 1756 olduğu hatırlanırsa, bu sıralarda mevcut kalyonları tesbit etmek, mevzuyu aydınlatmak bakımından önem arzeder. 1758'de donanmaya katılan ve bazı kayıtlarda Hısnül-bahr, bazı belgelerde de Hısn-ı bahrî olarak kaydedilen bir kalyon bulunmaktadır. ${ }^{40}$ Bu kalyon 1769 'da da donanma envanterindeydi. ${ }^{41}$ "Hısn"; kale, hisar, sığınılacak sağlam yer anlamlarına gelmektedir. Eserin muhtemel müellifi acaba kalyonun kendi adı yerine bu anlamı çağrıştıracak Kilîd-i bahrî ismini kullanmış olabilir mi? Hem bu şekilde mâninin sekizlik hece ölçüsü de tutturulmuş olmaktadır.

Bu ikinci açıklama tutarlı kabul edilmez ise bu kez şu sorunun cevabı bulunmalıdır: Mânide ekseriyetle 1718'den itibaren 1750'ler civarındaki kalyonların adı zikredilirken niye sadece 1800'lerin hemen başlarında donanmada görev alan hem de Ruslarla yapilan savaşta mağlup olan donanma gemileri arasında bulunan bir kalyon zikredilmeye değer bulunmuştur?

39 Yusuf A. Aydın, “18. Yüzyılda Osmanlı Devleti’nin Ege (Adalar) Denizi ve Doğu Akdeniz’e Yönelik Güvenlik Parametreleri”, Osmanlı Araştırmaları / The Journal of Ottoman Studies, 45 (2015), s. 166. Osmanlı donanmasında 1760'da sefere çıkan Hırz-ı Bahrî adında bir karavele kalyonu vardı. Kalyon, bu seferinde kazaya uğramış içindeki top ve mühimmatı sonradan çıkarılmışı (Aydın, Sultanın Kalyonları, s. 125).

40 Aydın, Sultanın Kalyonları, s. 126 (dip not 431).

41 Aydın, Sultanın Kalyonları, s. 125. 
10- Sarı kuşaklı kalyon:

Sarı Kuşaklı kalyon ile ilgili ilk kayıt 1714'te Akdeniz seferinde bir korsan gemisiyle çatışmaya girdiği hakkındadır. ${ }^{42}$ Bu kalyonla ilgili tesadüf edilen başka bir belgeye göre 1737 'de de sefere çıkmıştır. ${ }^{43}$

\section{1- Mavi kıçlı kalyon:}

Mavi kıçlı kalyonun 1718 'de donanma hizmetinde olduğuna dair kayıt bulunmaktadır. ${ }^{44}$

12- Isper [Esper] kıçlı kalyon:

Mânide "Ísper" şeklinde yazılmasına rağmen bu kelimenin Esper olması muhtemeldir. Esper bir tür doğan cinsidir. Donanmada bazı kalyonlara yırtıcı bir kuş adının verildiği bilinmektedir. ${ }^{45}$ Esper kıçlı isimli kalyona ait ilk kayıt 1718 yılındadır ve Patrona-i hümayun rütbesindeki bir komutana tahsis edilmiştir. ${ }^{46}$ 1730 'da mevcut donanma kalyonları listesinde kaydedilmiştir. ${ }^{47}$

\section{3- Kır At başlı kalyon:}

Donanmada "Kır" kelimesinin yerine aynı anlama gelen "Beyaz" kelimesinin kullanıldığı bir kalyon ismi bulunmaktadır. Beyaz At başlı adındaki bu kalyonla ilgili ilk kayı $1717^{\prime}$ e aittir. ${ }^{48} 55$ zira $(41,69$ m.) uzunluğundaki bu kalyonla ilgili tesadüf edilen son kayda göre 1730 'da donanma envanterinde bulunmaktadır. ${ }^{49}$

42 BOA, D. BŞM. KND dos. 1/48.

43 BOA, D. BŞM. KND dos. 7/38.

44 BOA, D. BŞM. KNK dos. 1/55. Bu isimde başka bir kalyon 1769'da donanmada hizmet görmekteydi (BOA, D. BŞM. TRE def. 14984, s. 2-4). Fakat bu aynı isim verilmiş başka bir kalyon olmalıdır.

45 Bu konu hakkında bkz. Yusuf A. Aydın, "Osmanlı Dönemi ve Öncesinde Avcı Kuşlardan Sungur Üzerine Bazı Notlar”, Tarih Dergisi, 57 (2013), s. 25-44.

46 BOA, MAD 3918, s. 27.

47 Aydın, Sultanın Kalyonları, s. 55.

48 BOA, MAD 2850, s. 44, 45.

49 Aydın, Sultanın Kalyonları, s. 54. 


\section{4- Yaldız kıçlı kalyon:}

Bazı kalyonların isimlendirilmeleri kıç kasaralarındaki balkon tipi dışarı çıkan yapının üzerine çizilen süslemeler ve tasvirlere nispetle Minâre bağģeli, Çifte bağģeli vs. şeklinde olmuştur. Bu yapılar geminin kıç kasarasında olduğundan bağçeli kelimesi yerine kıçlı kelimesinin kullanılması mümkündür. Mânide ikinci kelimeyi kullanmak mâniyi söyleyene ayrıca bir hece daha kazandıracaktır. Dolayısıyla bu kalyonun ismi Yaldız băg̣celi olarak da düşünülebilir. 46 zirâ (34,86 m.) uzunluğundaki bu kalyon $1714^{\prime}$ te seferdeydi. ${ }^{50} 1740$ 'da ise sefere çıkacak durumda olmadığından devlet tarafindan Abdullah Kaptan isimli birine 2250 kuruşa satılmışt. ${ }^{51}$

\section{5- Ay kıçlı kalyon:}

Mânide $A y$ kıçlı olarak zikredilen bu kalyon 1714 'te donanma mevcudunda olduğu tespit edilen $A y$ Bağģeli isimli kalyon olmalıdır. ${ }^{52}$ Bu kalyona dair tesadüf edilen son belge ise 1739 'da sefer dönüşünde Cebehane-i Âmire'ye teslim edilen barutla ilgilidir. ${ }^{53}$

\section{6- Yaldızlı hurma [kıçlı] kalyon:}

1714'te Patrona-i hümâyûn rütbeli donanma komutanın idaresinde Akdeniz seferine açılan 57,5 zirâ (43,58 m.) uzunluğundaki Yaldızlı Hurma kıçlı isimli kalyon ${ }^{54} 1740$ 'da görevden çıkarılmıştı. ${ }^{55}$

\section{7-18 Çifte bahçeli ve Ejder başlı kalyonlar:}

Bu kalyonlarla ilgili arşivde tesadüf edilen kayıtlar tarihlendirme konusunda yol gösterici olacaktır. Mânide Çifte Bahçeli ve Ejder Başlı isimli kalyonların Sinop’tan geldiği ifade edilmektedir. Osmanlı donanmasında görev alacak kalyonların inşası ana üs ve aynı zamanda en büyük inşa tezgahı konumunda olan İstanbul'daki Tersane-i Âmire'de gerçekleşmekteydi. Bunun yanı sıra Sinop, Midilli

50 BOA, MAD 3171, vr. 35b.

51 BOA, MAD 3389, s. 114. Söz konusu kalyon satılana kadar 50 gün müzâyedede kalmıştı (BOA, AE I. Mahmud 949).

52 BOA, $M A D 3171$, vr. 22a.

53 BOA, MAD 10340, s. 68.

54 BOA, $M A D 3171$, vr. 10b.

55 BOA, MAD 10329, s. 107. 
ve Rodos'ta da kalyon inşa edilmekteydi. ${ }^{56}$ Bu inşa organizasyonu bazı devlet görevlilerine yüklenirdi. Söz konusu iki kalyonun inşası Sinop’ta 1735 'te tamamlanmıştı. ${ }^{57}$ Aynı zamanda Osmanlı donanmasına katılan bu iki kalyon daha sonra $1755^{\prime}$ te, parçalarına ayrılmak suretiyle hizmetten çıkarılmışlardı. ${ }^{58}$

\section{Sonuç}

Mânide isimlerinin zikredilmesinin yanı sıra haklarında doğrudan bilgi verilenler Çifte Bahçeli ve Ejder Başl lisimli kalyonlardır. Bu kalyonların Sinop’tan geldiğine dair verilen bilgi arşiv belgeleriyle doğrulanmaktadır. Mânide bu iki kalyondan bahsedilirken “di” li geçmiş zaman kipinin kullanılmış olması mâninin söylendiği tarih ile ilgili önemli bir ayrıntıdır. Zira söz konusu kalyonlar $1755^{\prime}$ te donanma envanterinden çıkarılmışlardır. Dolayısıyla mâni 1755 yılından sonra söylenmiştir. Bu da Ahırkapı ile Çatladıkapı arasındaki fenerinin inşa edildiği tarih ile uyuşmaktadır. Çelebioğlu'nun eserin 18. yüzyılın ikinci yarısında vücuda getirildiğine dair değerlendirmesi bu bağlamda kesinlik kazanmaktadır. Bununla birlikte mâniyi söyleyen kişinin kendi yaşadığı zamandan 20-30 sene öncesine dair kalyonları niçin övmek ihtiyacı duyduğu şeklindeki soru da ayrıca cevaplanmayı beklemektedir. Bu durum muhtemelen mânideki kalyonların 18. yüzyılın ilk yarısında donanmanın başarı elde ettiği bir savaşta yer almış olmalarıyla ilgilidir.

Osmanlı donanmasının Akdeniz'de başarı elde ettiği bu savaş Mora’nın geri alınmasına yönelik düzenlenen sefer sırasındadır. 1716-1718 yıllarında Venedik donanmasına karşı üstünlük sağlayan Osmanlı donanması, Karlofça antlaşması (1699) ile terkedilen Mora yarımadasının Pasarofça antlaşması (1718) ile Venedik'ten geri alınmasını sağlamıştır. 1718'deki son çarpışmadan sonra kalyonlarda yaralanan personelin adlarının kaydedildiği listede ${ }^{59}$, bu vesileyle Mavi kıçlı, İsper kıçlı, Yaldız kıçlı, Ay kıçlı, Kır At başlı, Yaldızlı hurma, ve Sarı kuşaklı şeklinde

56 Aydın, Sultanın Kalyonları, s. 71-74. Bu hususta ayrıca bkz. Şenay Ö. Gümüş, "XVIII. Yüzyılda Midilli’de Osmanlı Donanması İçin Gemi İnşası”, Osmanlı Dönemi Akdeniz Dünyası, ed. H. Çoruh, vd., İstanbul 2011, s. 201-238.

57 53,5 zirâ $(40,55$ m.) uzunluğundaki her iki kalyon ile birlikte 17 ’şer zirâlık $(12,88 \mathrm{~m}$.) üçer adet sandal ve filikaları da inşa edilmişti. Bütün harcamalar göz önünde alındığında yaklaşık olarak bir kalyonun devlete mâliyeti 54.000 kuruş olmuştu (Aydın, Sultanın Kalyonları, s. 84).

58 Aydın, Sultanın Kalyonlar, s. 130.

59 Aydın, Sultanın Kalyonları, s. 315-319. 
kalyon adları geçmektedir. Savaşta yer alan bu kalyonlara bu esnada donanmanın envanterinde olan Kapudane, Patrona ve Riyâle kalyonları ile $\ddot{U}_{c}$ anbarl, $\ddot{U}_{\mathcal{G}}$ Kantarlı ve Karavele gibi genel adlar taşıyanlar da eklenebilir. Kısaca bütün bunlar dikkate alındığında edebî türdeki bir metinden denizcilik tarihine dair önemli tesbitlerin yapılabileceği, bu tür metinlerin müstağni kalınamayacak "beklenmedik şekilde” bir yeni kaynak türünü, en azından buradaki araştırma muvacehesinde belirlediği söylenebilir.

Mânilerden Kalyonları Ögrenmek: Ramazan-nâme Metnindeki Osmanlı Kalyonları ile İlgili Bilgilerin Değerlendirilmesi

Özet - Osmanlı Denizcilik Tarihi son zamanlarda üzerinde çalışmalar yapılan bir tarih sahası olarak dikkat çekmektedir. Bu sahanın esas konularından birini Osmanlı donanması oluşturmaktadır. Söz konusu akademik çalışmalar genel itibariyle arşiv belgelerine dayalı olarak hazırlanmaktadır. Arşiv belgelerinin yanı sıra Osmanlı dönemi edebî metinlerinde de Osmanlı Denizcilik Tarihi'ne dair bazı bilgiler bulunmaktadır. Bunlardan biri de Halk Edebiyatı kapsamındaki mânilerdir. Âmil Çelebioğlu tarafindan neşredilen Ramazan-nâme, mânilerin yer aldığı bir yazma eserdir. Bu eserdeki mânilerden birinde 18. yüzyıldaki Osmanlı donanması kalyonları zikredilmektedir. Bu da bize denizcilik tarihinin yeniden okunabileceği farklı kaynak türlerine açılmayı sağlamaktadır. Bu makalede söz konusu mâniden hareketle zikredilen kalyonların arşiv ve kitabî kaynaklara dayalı tesbitleri yapılmıştır. Ayrıca bu metnin tarihlendirmesi söz konusu kalyonlarla ilgili yaptığımız tarihî araştırmada ortaya çıkmışıı. Elimizdeki arşiv kaynakları, isimleri belirtilen kalyonların en geç 1750 'li yıllara kadar Osmanlı donanmasının envanterinde yer aldığını göstermektedir. Öte yandan kalyon adlarının böyle bir maniye konu teşkil etmesinin altında Osmanlıların başarılı Mora seferi (1716-1718) sırasındaki deniz harekatının yattığı da anlaşılmaktadır

Anahtar Kelimeler: Ramazan-nâme, Mâni, Osmanlı donanması, Kalyon adları, Mora Seferi 


\section{Kaynaklar}

\section{Arşiv Belgeleri}

Başbakanlık Osmanlı Arşivi (BOA):

Ali Emîrî (AE) I. Mahmud 949.

Bâb-1 Defteri, Başmuhâsebe Kalemi-Kalyon Defterdârlığı (D. BŞM. KND) dos. 1/48, 55; $7 / 38$.

Cevdet-Bahriye (C. BH) 893; 1154; 2196; 5534.

Bâb-1 Defteri, Başmuhâsebe Kalemi-Kalyon Kâtibliği (D. BŞM. KNK) dos. 1/55.

Maliyeden Müdevver Defterler (MAD) 2850; 3171; 3389; 3918; 10325; 10329; 10340.

Bâb-ı Defteri, Başmuhâsebe Kalemi, Tersâne Emini Defteri (D. BŞM. TRE def.) 14984.

\section{Basılı Kaynaklar}

Şem'dânî-zâde Fındıklılı Süleyman Efendi, Mür'i't-Tevârih, I, haz. M. Aktepe, İstanbul 1976; II. A, İstanbul 1978.

Çeşmî-zâde Mustafa Reşîd, Çeşmî̀-zâde Tarihi, haz. B. Kütükoğlu, İstanbul 1993.

Albayrak, N. “Mâni”, DİA, XXVII (2003), s. 571-573.

Aydın, Y. A., “18. Yüzyılda Osmanlı Devleti’nin Ege (Adalar) Denizi ve Doğu Akdeniz’e Yönelik Güvenlik Parametreleri”, Osmanlı Araştırmaları / The Journal of Ottoman Studies 45 (2015), s. 161-184.

Aydın, Y. A., Sultanın Kalyonları, Osmanlı Donanmasının Yelkenli Savaş Gemileri (17011770), İstanbul 2011.

Aydın, Y. A., "Osmanlı Dönemi ve Öncesinde Avcı Kuşlardan Sungur Üzerine Bazı Notlar”, Tarih Dergisi, 57 (2013), s. 25-44.

Bostan, İ., Kürekli ve Yelkenli Osmanlı Gemileri, İstanbul 2005.

Çelebioğlu, Â., Ramazan-nâme, 1826 Yılından Ramazan Mânileri, İstanbul 1974.

Çelebioğlu, Â., "Eski Türk Edebiyatında Gemiyle İlgili Şiirler ve Bazı Hususiyetler”, Eski Türk Edebiyatı Araştırmaları, İstanbul 1998, s. 625-654.

Emeksiz, A., İstanbul Mânileri, İstanbul 2007.

Gümüş, Ş. Ö., "XVIII. Yüzyılda Midilli'de Osmanlı Donanması İçin Gemi İnşası”, Osmanlı Dönemi Akdeniz Dünyası, ed. H. Çoruh, vd., İstanbul 2011, s. 201-238.

Kahane, H. \& R., Andreas Tietze, The Lingua Franca in the Levant, Turkish Nautical Terms of Italian and Greek Origin, İstanbul 1988.

Müller-Wiener, W., Bizans'tan Osmanliya İstanbul Limanı, İstanbul 1998.

Sarıcaoğlu, F., “Osman III”, DİA, XXXIII (2007), s. 456-459. 
MÂNİLERDEN KALYONLARI ÖĞRENMEK: RAMAZAN-NÂME METNINDEKİ OSMANLI KALYONLARI İLE İLGİLİ BİLGILLERIN DEĞERLENDİRİLMESİ

Tosun, M., “Şan-1 Devlet-i Aliyye’yi Korumak ya da Edirne Sarayı'nı Tamir Etmek”, Journal of History Studies, 184 (2014), s. 183-194.

Tredrea, J., E. Sozaev, Russian Warships in the Age of Sail, 1696-1860. Design, Construction, Careers and Fates, Great Britain 2010.

Zorlu, T., Osmanl ve Modernleşme, III. Selim Dönemi Osmanl Denizciliği, İstanbul 2014, s. 199-207. 